\title{
Eutrophication of Lake Tasaul, Romania-proposals for rehabilitation
}

\author{
Mihaela Laurenta Alexandrov • Jürg Bloesch
}

Received: 25 April 2008 / Accepted: 24 October 2008 /Published online: 9 January 2009

(C) Springer-Verlag 2008

\begin{abstract}
Lake Tasaul on the Black Sea coast is highly eutrophic, but not strongly contaminated (heavy metals, PAHs, and organochlorine pesticides). Cyanophytes dominate phytoplankton by $67-$ $94 \%$ and form frequent algal blooms. High primary production (up to $270 \mathrm{mg} \mathrm{C}_{\text {ass }} / \mathrm{m}^{2}$.h) and algal biomass (maximum chlorophyll $a$ concentration $417 \mu \mathrm{g} / \mathrm{l})$ may be controlled by light, as Secchi depth is often below $1 \mathrm{~m}$. The main tributary, Casimcea River, provides high quantities of suspended matter and about 3 tons TP/year and 660 tons TN/year. Based on chemical and biological analysis as well as fishery investigations, we provide recommendations for Lake Tasaul rehabilitation.
\end{abstract}

Keywords Biomass $\cdot$ Black Sea $\cdot$ Contamination .

ESTROM · Eutrophication · Fishery · Lake management .

Lake Tasaul · Nutrient load · Primary production · Romania .

Tasaul project

ESPR Special Issue-ESTROM

Responsible editor: Walter Giger

M. L. Alexandrov $(\bowtie)$

National Institute for Marine Research and Development,

'Grigore Antipa',

Bd. Mamaia 300,

900581 Constanta, Romania

e-mail: laurenta@alpha.rmri.ro

J. Bloesch

Eawag, Swiss Federal Institute of Aquatic

Science and Technology,

Überlandstrasse 133,

CH-8600 Dübendorf, Switzerland

e-mail: bloesch@eawag.ch

\section{Background, aim, and scope}

Black Sea coastal lakes are important and threatened ecosystems. In the 1920s, Lake Tasaul (area $23.35 \mathrm{~km}^{2}$, maximum depth $4 \mathrm{~m}$ ) near Constanta has been transformed by technical structures from an open coastal lagoon (salt water) to a freshwater lake (no outlet, shallow, turbulent, and eutrophic), classified as heavily modified water body according to the EU Water Framework Directive. Lake Tasaul has been used mainly for aquaculture and fish production. We hypothesize that the drastic decline in fishcatch in 1994-1995 from 180 to $50 \mathrm{t}$, and further to $5 \mathrm{t}$ until 2000 (Alexandrov et al. 2008), was the direct response of the lake ecosystem to a trophic change, in combination with diminished fish reproduction.

\section{Materials and methods}

Our limnological survey was performed from May 2005 to June 2007. Figure 1 shows the sampling sites. Sediment cores were taken by a gravity corer $(90 \mathrm{~mm}$; Uwitec, Mondsee, Austria, No. 019001). Commonly used methods (most of them standardized for the Black Sea area) were applied for chemical water and sediment analysis, biological investigations, and species identification (NIMRD 2006). Primary production was measured with the ${ }^{14} \mathrm{C}$ technique using acid bubbling (Gächter and Mares 1979). Nutrient load of tributaries was calculated by a regression model (Fourier-polynom-function) based on discharge measured by limnigraphs and nutrient concentrations from discharge-proportional samples (IGKB 1989). 


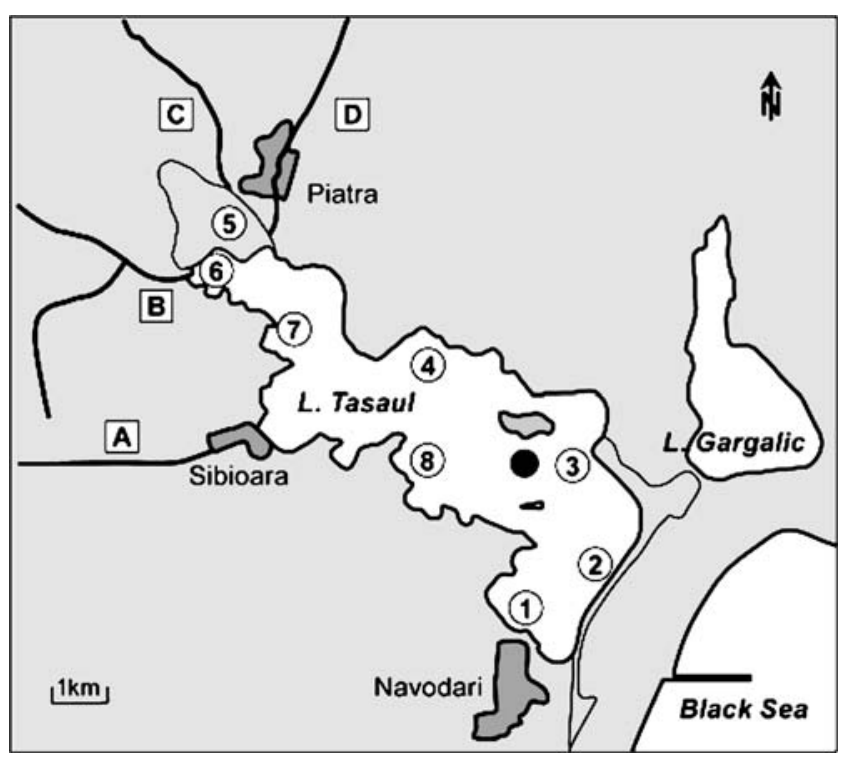

Fig. 1 Sampling sites in Lake Tasaul and major tributaries ( $A$ Sibioara River, $B$ Dalufac River, $C$ Casimcea River, $D$ Piatra River). Stations 1-8: sampled in 2005-2006 at the lake surface; station marked with black point (deepest site): sampled by depth profiles in 2006-2007; stations A-C near the river mouths: sampled during 2006-2007 (D gauging only)

\section{Results}

Nutrient concentrations (SRP mean lake concentration $\left.17 \mu \mathrm{g} / \mathrm{l}, \mathrm{NO}_{3}-\mathrm{N} 370 \mu \mathrm{g} / \mathrm{l}\right)$ reflected the eutrophic state of Lake Tasaul (Table 1). The N/P ratios (mean 125) exceeded the Redfield's ratio (16:1) significantly and point toward Plimitation, although light may play a crucial role at times of

Table 1 Lake Tasaul chemistry (selected parameters), May 2005November 2007

\begin{tabular}{lcc}
\hline Parameter & Mean value $( \pm \mathrm{SD})$ & Range \\
\hline Salinity (\%) & $0.95 \pm 0.389$ & $0.24-2.67$ \\
Alkalinity (meq/l) & $5.6 \pm 0.37$ & $4.4-6.7$ \\
$\mathrm{pH}$ & $8.7 \pm 0.46$ & $7.6-9.6$ \\
$\mathrm{O}_{2}(\mathrm{mg} / \mathrm{l})$ & $12.4 \pm 2.41$ & $3.9-17.1$ \\
$\mathrm{O}_{2}$ saturation $(\%)$ & $132 \pm 26.1$ & $62-210$ \\
$\mathrm{SRP}(\mathrm{mg} / \mathrm{l})$ & $0.017 \pm 0.0121$ & $0.003-0.070$ \\
$\mathrm{TP}(\mathrm{mg} / \mathrm{l})$ & $0.106 \pm 0.1435$ & $0.023-0.899$ \\
$\mathrm{NO}{ }_{3}-\mathrm{N}(\mathrm{mg} / \mathrm{l})$ & $0.37 \pm 0.419$ & $0.02-1.71$ \\
$\mathrm{TN}(\mathrm{mg} / \mathrm{l})$ & $1.884 \pm 0.641$ & $0.852-3.784$ \\
$\mathrm{TOC}(\mathrm{mg} / \mathrm{l})$ & $16.318 \pm 3.763$ & $8.430-23.050$ \\
$\mathrm{Chl} a(\mu \mathrm{g} / \mathrm{l})$ & $164.3 \pm 122.6$ & $8.6-417.0$ \\
Atomic N/P ratio & $125 \pm 108$ & $4.7-451$ \\
\hline
\end{tabular}

During May 2005-March 2006, surface samples from eight stations; during April 2006-November 2007, vertical profiles at mid-lake station (see Fig. 1) high turbidity (see below). Horizontal differences did not show a consistent pattern and were smaller than seasonal variation (Alexandrov 2008, in preparation). The water column was well mixed throughout the seasons, and oxygen concentrations revealed a routine oversaturation up to $210 \%$. However, some oxygen depletion was observed occasionally near the lake bottom (minimum $3.9 \mathrm{mg} \mathrm{O}_{2} / 1$ and $62 \%$ saturation). The sediments showed anoxic black layers below the surface indicating strong gradients of dissolved components and a high potential for internal nutrient loading. Consistent, wind-induced sediment resuspension fosters intensive nutrient cycling. Significant external nutrient load from Casimcea River (as the main tributary), was estimated to be about 3 tons TP/year and 660 tons TN/ year (these are minimum values as some high flow events contributing the main proportion to the annual load could not be sampled as planned). The input of Sibioara and Dalufac Rivers were relatively low, as these small rivers have a much smaller catchment than Casimcea River.

High nutrient concentrations in spring favored green algae (Scenedesmus), blue-greens (Oscillatoria, Microcystis), and brackish species, while diatoms were scarce (salinity is in the range of $0.2-2.7 \%$ ). Phytoplankton showed frequent blooms (Cyanophyta, Euglenophyta). The species lists showed a high biodiversity (Phytoplankton 69 species; zooplankton 35 species). Zooplankton was dominated by rotifers with a low diversity and productivity. There was a lack of Cladocerans. The biomass (fresh weight) of various biological compartments peaked at $38 \mathrm{mg} / \mathrm{l}$ (phytoplankton), $9.5 \mathrm{mg} / \mathrm{l}$ (zooplankton), and $39 \mathrm{mg} / \mathrm{m}^{2}$ (benthos). The total number of bacteria was $5 \times$ $10^{3}-1.6 \times 10^{6} / \mathrm{ml}$, and two stations with anthropogenic influence showed increased bacteria concentrations including pathogenic forms. The low benthos abundance (no Mysids and Amphipods) can be explained by anoxic sediments providing unsuitable habitat for bottom fauna. A check of persistent contaminants such as PAHs, PCBs and heavy metals showed significant temporal and spatial variation, but no severe pollution as mostly below critical threshold values in water and in sediments stipulated in national regulations: Total hydrocarbons showed a mean concentration of $381 \mu \mathrm{g} /$ 1 in water and $2,126 \mu \mathrm{g} / \mathrm{l}$ at the surface of sediments, polyaromatic hydrocarbons (15 components) in total were $702 \mathrm{ng} / \mathrm{g}$ at sediment surface, organochlorine pesticides (nine components) showed a total mean concentration of $1,793 \mathrm{ng} /$ 1 in water and $254 \mathrm{ng} / \mathrm{g}$ in sediments, trace heavy metals showed a maximum concentration for $\mathrm{Cu}$ in water (12.57 $\mu \mathrm{g} / \mathrm{l}$, range 3.07-48.32 $\mu \mathrm{g} / \mathrm{l})$ and $\mathrm{Pb}$ in sediments (73.95 $\mu \mathrm{g} / \mathrm{g}$ d.w., range $26.90-125.87 \mu \mathrm{g} / \mathrm{g}$ d.w.; Alexandrov 2008 , in preparation).

Hourly, primary production amounted to $80-2,712 \mathrm{mg}$ $\mathrm{C}_{\text {ass }} / \mathrm{m}^{2} \cdot \mathrm{h}$ and was concentrated in the top meter of water column during a large part of the year according to the 
measured light profiles and low transparency (Fig. 2). Hence, algal production may be limited not only by nutrients, but also by self-shading effects of dense algal biomass increasing turbidity, which is also caused by resuspended sediments. The calculation of daily and annual primary production is in progress.

Fish stock in Lake Tasaul was assessed in 2005 for two out of eight species (Carassius gibelio [giebel carp] and Rutilus rutilus [roach]) from a total of 581 specimens investigated (Alexandrov et al. 2008). FAO-related methods were applied by using "age-structured" models based on population parameters such as length frequency diagrams and length-weight relationships. Biomass in 2005 was 23.6 tons for giebel carp and 34.2 tons for roach. Since the fishing mortality coefficient was greater than the natural mortality coefficient, fishery is claimed not to be sustainable (i.e., as a result of overexploitation). The maximum sustainable yield, according to the model based on standard fish catch of 10 tons/year, would be 10.9 tons/year for giebel carp and 12.2 tons/year for roach.
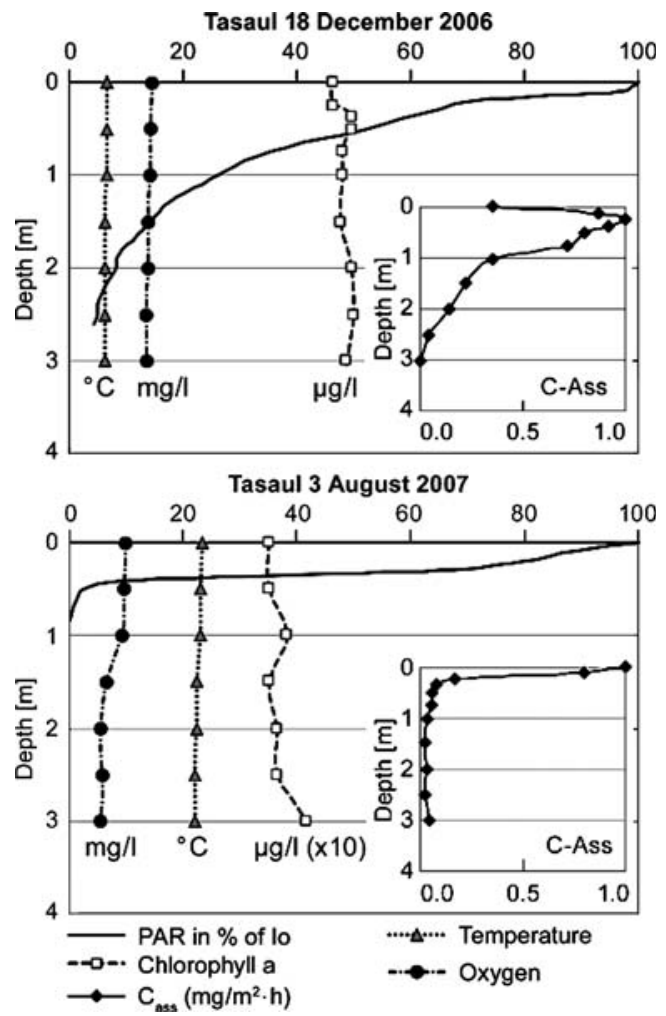

Fig. 2 Typical temperature $\left({ }^{\circ} \mathrm{C}\right)$, oxygen $(\mathrm{mg} / \mathrm{l})$, chlorophyll $a(\mu \mathrm{g} / \mathrm{l})$, light PAR (in \% of Io) and ${ }^{14} \mathrm{C}\left(\mathrm{mg} \mathrm{C}_{\text {ass }} / \mathrm{m}^{2} \cdot \mathrm{h}\right)$ profiles in Lake Tasaul (upper panel: winter, lower panel: summer). Note the scale/tenfold higher concentration of chl. $a$ in summer

\section{Discussion}

Our limnological investigation proved the highly eutrophic state of Lake Tasaul. It is likely that the biota is not biased by contamination and bottom up controlled by nutrients originating mainly from internal and external loading. Shallow lakes are naturally eutrophic systems. Internal nutrient loading triggered by bottom sediment resuspension may encompass external loading from point and diffuse sources. Since Lake Tasaul is mainly used for fisheries, general measures for lake protection/restoration are the basic prerequisites for fish reproduction. It is not likely that contaminants bias fish life in Lake Tasaul. We could not quantify the role of turbidity and nutrients (bottom up control) vs significant water fowl as fish predators (top down control). However, lack of scientifically based management, reduced fish reproduction due to unfavorable conditions, and overfishing by man may be at least partly responsible for the decline of fish yield. Hence, apart from the classical limnological remedies such as nutrient input reduction, the fishery management strategy must be in the focus of restoration measures (stocking programs, regulation of mesh-size of fishing nets for professional fishery, regulation of sport fishery and licenses, control of poaching, optimization of the role of fish hatchery, etc).

On the basis of our experience, a nutrient mass balance of Lake Tasaul can only be achieved if the sampling strategy can be optimized and lake output and ground water interactions can be assessed by investigating the complex hydrology at the south shore of Lake Tasaul (outlet now closed by abandoned channels, unpredictable groundwater exfiltration) and measuring an accurate nutrient lake output.

\section{Conclusions}

Recommendations toward reduction of eutrophication and a more sustainable fishery management in Lake Tasaul are: (1) to reduce nutrient input of Casimcea River by fighting point sources; (2) to continue the general monitoring, hydrology, nutrients, primary production, and fish production in particular; (3) to perform a detailed monitoring of yearly restocking to quantify fishing effort/ input; (4) to perform detailed statistics about net catches and angling, and estimate poaching, to quantify fishing/ output.

\section{Recommendations and perspectives}

Restocking may sustain fish stocks, but biomanipulation would be very difficult. The goal to rehabilitate Lake 
Tasaul's water quality and natural resources may be achieved best by implementing a management plan for the whole catchment. Applying GIS systems and maps based on a data base, which is continuously improved, can be very supportive.

Acknowledgement This work was financed by the Swiss National Science Foundation, the Swiss Agency for Development and Cooperation and the Romanian Ministry for Education and Research within the framework of the Swiss-Romanian cooperation program on "Environmental Science and Technology in Romania-ESTROM". The reported study was performed in the project TASAUL, focusing on the assessment of anthropogenic impacts on Tasaul Lake, Romania, and ecosystem rehabilitation. We greatly acknowledge Daniela Mircea-Rosioru, Dan Vasiliu, Razvan Mateescu, Victoria Smocov, Victoria Piescu, Valentina Coatu, Andra Oros, Adriana Cociasu, and NIMRD-Constanta staff for their cooperation, as well as Irina Cernisencu from DDNIRD, Andreas Kohler, Hanspeter Hodel, Alessandro Grasso, Bernhard Luder, Daniel Wyder (FOEN-Landeshydrologie), Peter Bossard,
Daniel Steiner, Mike Sturm, Heinrich Bührer (Eawag) for their support.

\section{References}

Alexandrov ML, Cernisencu I, Bloesch J (2008) History and concepts of sustainable fishery in Tasaul Lake, Romania. Proceedings of Swiss-Romanian Research Programme on Environmental Science \& Technology (ESTROM), Geo-Eco-Mar 14:61-71

Gächter R, Mares A (1979) Comments to the acidification and bubbling method for determining phytoplankton production. Oikos 33:69-73

IGKB (Internationale Gewässerschutzkommission für den Bodensee) (1989) Die Belastung des Bodensees mit Phosphor- und Stickstoffverbindungen, organisch gebundenem Kohlenstoff und Borat im Abflussjahr 1985/86. Bericht Nr.40

NIMRD (National Institute for Marine Research and Development) (2006) Guidelines chemical methods for water and sediment analysis, biological methods and species identification 